\title{
Interprofessional Education: Hybrid Modalities for Health Professionals Training
}

\author{
Maureen Rubin \\ Aurora University \\ Julie Thomas \\ University of Nevada \\ Carrie Hintz \\ University of Nevada \\ Shawn Thomas \\ University of Nevada
}

\begin{abstract}
Several barriers contribute to the failure in achieving competency in Interprofessional Education (IPE). The hybrid IPE modality was designed to enhance student mastery of interprofessional communication and teamwork competencies. A hybrid model of instruction implemented to enhance interprofessional education for students in social work, nursing, and physician assistant programs. There were significant improvements in mastery of competencies as demonstrated through the ICCAS survey, demonstrating the use of hybrid IPE can improve collaboration among interprofessional teams. Hybrid IPE experiences can facilitate student engagement and mastery of IPEC competencies.
\end{abstract}

Keywords: interprofessional education, healthcare, competencies

\section{INTRODUCTION}

Interprofessional Education (IPE), and the execution of a well thought out IPE pedagogy, will play a critical role in improving the future of healthcare in the United States. In 2018, Nevada was ranked 50th nationwide for healthcare rankings by the Agency for Healthcare Research and Quality (Bekker, 2018). Although the ranking is considered relative to other states, access to healthcare remains a concern for Nevada. One reason for this can be attributed to the segmented health care services that exist in the community. Interprofessional educational opportunities enable students to acquire the knowledge and skills necessary to become collaborative change agents for healthcare improvement. There is greater overall benefit to patients when healthcare education is based on the understanding of healthcare as a larger system instead of individual parts. 


\section{BACKGROUND}

The Institute of Medicine (IOM) (2010) report called on health education institutions to educate students on the importance of collaborative interprofessional teams as a means to improve patient safety and quality of care. Since this report, educational accreditation commissions and agencies have incorporated interprofessional education into their academic standards for professional healthcare training. Research also demonstrates that the implementation and use of IPE improves patient safety and quality care delivery strategies (Blue et al., 2010). Further, it enables students to recognize the value of interprofessional engagement as a key component of collaborative patient care (McPherson, Headrick, \& Moss, 2001).

The Interprofessional Education Collaborative (IPEC) is an internationally recognized group whose mission, in collaboration with academic institutions, is to ... "promote, encourage, and support efforts to prepare future health professionals so that they enter the workforce ready for interprofessional collaborative practice that helps to ensure the health of individuals and populations" (Interprofessional Education Collaborative [IPEC], 2018, para 2). There are currently 20 associations across health professions schools that cooperate with IPEC. IPEC is also supported by four competency domains: Values and Ethics for Interprofessional Practice, Roles and Responsibilities, Interprofessional Communication, and Teams and Teamwork. These competencies provide a contextual foundation for selecting teaching strategies and instructional methods that are best suited to meet individual IPE activity objectives. It also provides a framework to evaluate IPE activity successes and challenges when piloting new teaching modalities (Simpson, Fenzel, Rhem, \& Marcdante, 2010).

As the IOM recommends a broader interdisciplinary approach to healthcare, endorsing collaboration in the education of healthcare professionals ensures full partnership in patient care (Institute of Medicine $[\mathrm{IOM}], 2001)$. Additionally, the American Association of Colleges of Nursing (AACN) also supports the incorporation of interprofessional communication and collaboration for improving patient health outcomes (American Association of Colleges [AACN], 2008). Collaboration is imperative in improving healthcare outcomes. As such, students are encouraged to participate in interprofessional educational opportunities aimed at improving these outcomes.

Historically, several barriers have contributed to the failure to implement IPE. Pedagogical impediments, logistical challenges, allocation of resources, deep-rooted hierarchical philosophies, and culture, as well as resistance to change are common reasons for failure (De Los Santos, McFarlin, \& Martin, 2014). De Los Santos et al. (2014) acknowledge the continued difficulties in implanting quality IPE educational experiences, which can result in graduates who are ill prepared to work within or collaborate with interprofessional teams. In the past several years, online instruction has emerged as a potential solution to this problem. Students and faculty can break down barriers and silos adopting distance teaching using online learning management systems (LMS) and video conferencing programs (Fowler et al., 2018).

\section{Hybrid IPE}

Online learning has emerged as an effective and growing part of many health professional education programs. Hybrid IPE experiences blend face-to-face instruction with the use of LMS instruction and video conferencing opportunities. The hybrid experience provides the opportunity for programs to collaborate through the use of innovative technology designed to augment traditional teaching modalities. The advantages of online learning include diminished logistical barriers and individualized, tailored, point-of-care learning that meets the varied needs of professional learners from multiple practice settings. Such benefits strengthen interprofessional learning, with economic savings and decreased travel costs students, as well as interactive experiences not bound by time or geographic limitations (McKenna et al., 2014).

Learner isolation and technical problems associated with LMS have been identified as potential problems with hybrid learning (Reeves, Fletcher, McLoughlin, Yim, \& Patel, 2017). However, hybrid learning can aid students in the development of their professional identity through engagement with the 
course, as well as interprofessional activities with other allied health professionals. Critical resources needed to aid in professional identity development include commitment to IPE experiences from departments and colleges, diverse calendar agreements, curricular mapping, mentor and faculty training, adequate physical space, technology, and community relationships (Bridges, Davidson, Odegard, Maki, \& Tomkowiak, 2011). These factors can be addressed and accounted for within individualized hybrid IPE experiences.

\section{IPE HYBRID METHODOLOGY}

Founded in 1874, the University of Nevada supports approximately 20,000 students across 145 academic majors. As the state's only land grant institution, the University has a mandated responsibility to ensure the training of the state's future workforce. The University has also recently received a Carnegie R1 designation, which signifies its commitment to support institutional diversity and inquiry across educational disciplines. The collaborative programs at the University incorporate the IPEC competencies and use the assessment and measurement of outcomes related to these competencies to demonstrate compliance with IPE-related accreditation standards. In pursuit of enhanced inter-programmatic collaboration, the School of Social Work, the School of Medicine Physician Assistant Studies Program, and the School of Nursing faculty formed an IPE work group to formulate a hybrid method for delivering IPE experiences to students. In addition to the four IPEC competencies, each health profession identified profession-specific competencies that should be demonstrated at the undergraduate or graduate level of education.

The collaborative IPE experience was designed to enhance student understanding of the importance of complementary roles in healthcare, supporting the needs of patient-centered care (AACN, 2008). Exposure to baseline competencies in education is an essential foundational component to the lifelong learning process inherent in the health professions. The IPE experience provided the students with a necessary exposure to interdisciplinary collaboration with shared goals, clear role expectations of all interdisciplinary team members, and the establishment of a flexible patient-centered care plan optimized by the healthcare team.

Educational isolation in the healthcare disciplines encourages the maintenance of historical stereotypes leading to poor communication, limited collaboration, and ineffective team-oriented environments. The IPE faculty team conceptualized an IPE module to be implemented through hybrid modality to address the challenges that are typical in higher education settings with a combination of faceto-face learning and online discussions to ensure true collaboration between professions (Collins et al., 2017). This was designed to ensure that different aspects of the module were threaded throughout the course. This blended modality allowed a degree of flexibility, which was intentionally planned and implemented to ensure seamless implementation of the IPE module in various courses in the three program.

Each participating school had learning outcomes specific to their program in relation to the IPE hybrid modules objectives. As such, the IPE student learning outcomes were mapped to the corresponding IPEC competencies. Figure 1 depicts the synergistic relationship composing the IPE Module Framework. Table 1 highlights the IPE module curricular mapping for the three professions. 
FIGURE 1

\section{IPE MODULE FRAMEWORK}

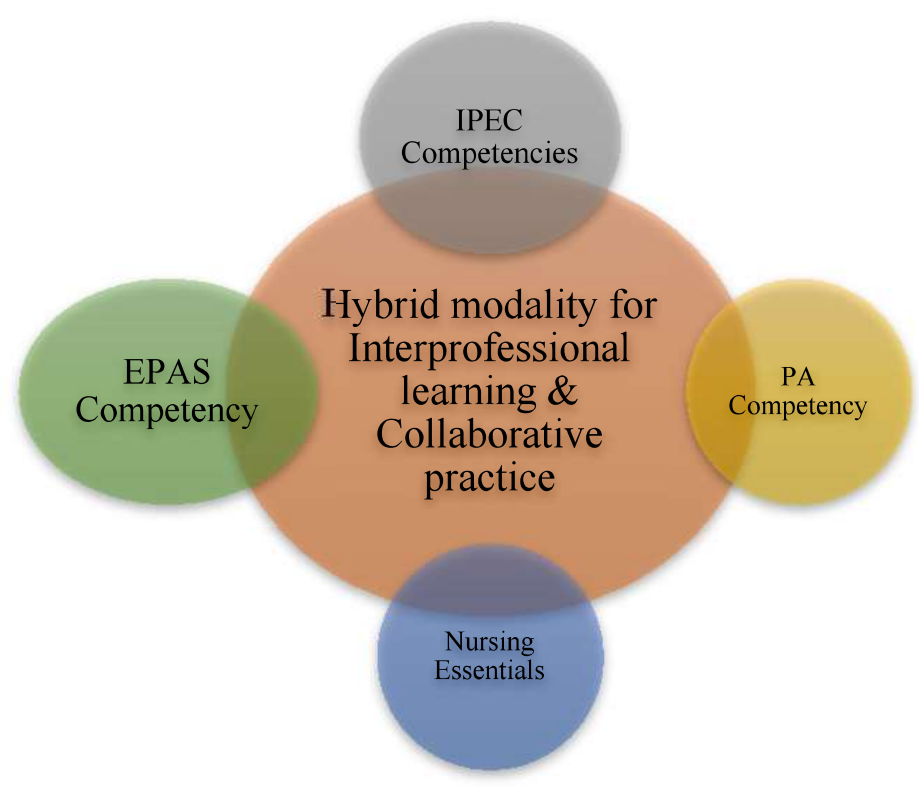

TABLE 1

IPE COPETENCY MAP

\begin{tabular}{|c|c|c|c|c|}
\hline $\begin{array}{c}\text { IPEC } \\
\text { Competency \& } \\
\text { Description } \\
\end{array}$ & $\begin{array}{c}\text { EPAS } \\
\text { Competency } \\
\text { (Social Work) } \\
\end{array}$ & PA Competency & $\begin{array}{c}\text { Nursing } \\
\text { Competency }\end{array}$ & $\begin{array}{c}\text { Course Student } \\
\text { Learning Outcomes } \\
\text { (SW, PA \& Nursing) }\end{array}$ \\
\hline $\begin{array}{l}\text { Values/Ethics for } \\
\text { Interprofessional } \\
\text { Practice } \\
\text { Work with } \\
\text { individuals of } \\
\text { other professions } \\
\text { to maintain a } \\
\text { climate of mutual } \\
\text { respect and shared } \\
\text { values. }\end{array}$ & $\begin{array}{l}\text { \#1: Demonstrate } \\
\text { Ethical and } \\
\text { Professional } \\
\text { Behavior } \\
\text { Social workers } \\
\text { understand the } \\
\text { profession's } \\
\text { history, its } \\
\text { mission, and the } \\
\text { roles and } \\
\text { responsibilities of } \\
\text { the profession. } \\
\text { Social Workers } \\
\text { also understand } \\
\text { the role of other } \\
\text { professions when } \\
\text { engaged in } \\
\text { interprofessional } \\
\text { teams. }\end{array}$ & $\begin{array}{l}2.1 \text { : } \\
\text { Demonstrates a } \\
\text { pattern of } \\
\text { therapeutic and } \\
\text { ethically sound } \\
\text { relationships with } \\
\text { patients. }\end{array}$ & $\begin{array}{l}\text { Essential VI: } \\
\text { Interprofessional } \\
\text { Communication } \\
\text { and Collaboration } \\
\text { for Improving } \\
\text { Patient Health } \\
\text { Outcomes } \\
\text { Interprofessional } \\
\text { education enables } \\
\text { the baccalaureate } \\
\text { graduate to enter } \\
\text { the workplace with } \\
\text { baseline } \\
\text { competencies and } \\
\text { confidence for } \\
\text { interactions and } \\
\text { with } \\
\text { communication } \\
\text { skills that will } \\
\text { improve practice, }\end{array}$ & $\begin{array}{l}\text { - Provide a strengths- } \\
\text { based, person-in- } \\
\text { environment social } \\
\text { work perspective as a } \\
\text { member of a multi- } \\
\text { disciplinary team } \\
\text { (SW) } \\
\text { - Describe the PA Code } \\
\text { of Professional Ethics } \\
\text { and how it applies to } \\
\text { patient care. Discuss } \\
\text { medical ethics as it } \\
\text { applies to all health } \\
\text { care professionals. } \\
\text { (PA) } \\
\text { Apply social and } \\
\text { ethnic factors and } \\
\text { concepts of cultural } \\
\text { diversity in providing } \\
\text { care for individuals, } \\
\text { families, and }\end{array}$ \\
\hline
\end{tabular}




\begin{tabular}{|c|c|c|c|c|}
\hline $\begin{array}{c}\text { IPEC } \\
\text { Competency \& } \\
\text { Description } \\
\end{array}$ & $\begin{array}{c}\text { EPAS } \\
\text { Competency } \\
\text { (Social Work) } \\
\end{array}$ & PA Competency & $\begin{array}{c}\text { Nursing } \\
\text { Competency }\end{array}$ & $\begin{array}{c}\text { Course Student } \\
\text { Learning Outcomes } \\
\text { (SW, PA \& Nursing) }\end{array}$ \\
\hline & & & $\begin{array}{l}\text { thus yielding better } \\
\text { patient outcomes. }\end{array}$ & $\begin{array}{l}\text { populations across the } \\
\text { lifespan and } \\
\text { continuum of care. }\end{array}$ \\
\hline $\begin{array}{l}\text { Roles/ } \\
\text { Responsibilities: } \\
\text { Use the knowledge } \\
\text { of one's own role } \\
\text { and those of other } \\
\text { professions to } \\
\text { appropriately } \\
\text { assess and address } \\
\text { the health care } \\
\text { needs of patients } \\
\text { and to promote } \\
\text { and advance the } \\
\text { health of } \\
\text { populations. }\end{array}$ & $\begin{array}{l}\text { \#6: Engage with } \\
\text { Individuals, } \\
\text { Families, Groups, } \\
\text { Organizations, and } \\
\text { Communities } \\
\text { Social workers } \\
\text { value principles of } \\
\text { relationship- } \\
\text { building and } \\
\text { interprofessional } \\
\text { collaboration to } \\
\text { facilitate } \\
\text { engagement with } \\
\text { clients, } \\
\text { constituencies, and } \\
\text { other professionals } \\
\text { as appropriate. }\end{array}$ & $\begin{array}{l}5.1 \text { : Demonstrates } \\
\text { understanding of } \\
\text { practice-specific } \\
\text { legal and } \\
\text { regulatory } \\
\text { requirements and } \\
\text { the role of the } \\
\text { physician } \\
\text { assistant as a } \\
\text { member of the } \\
\text { healthcare team. }\end{array}$ & $\begin{array}{l}\text { Essential I: Liberal } \\
\text { Education for } \\
\text { Baccalaureate } \\
\text { Generalist Nursing } \\
\text { Practice } \\
\text { Participate in the } \\
\text { development and } \\
\text { implementation of } \\
\text { imaginative and } \\
\text { creative strategies } \\
\text { to enable systems to } \\
\text { change. }\end{array}$ & $\begin{array}{l}\text { - Integrate information } \\
\text { from multiple sources } \\
\text { of information and } \\
\text { research to inform } \\
\text { assessments (SW) } \\
\text { - Describe the history } \\
\text { of the PA profession } \\
\text { in the U.S. and in } \\
\text { Nevada, and the } \\
\text { important role of the } \\
\text { PA in rural health } \\
\text { care. (PA) } \\
\text { - Participate in the } \\
\text { development and } \\
\text { implementation of } \\
\text { imaginative and } \\
\text { creative strategies to } \\
\text { enable systems to } \\
\text { change. } \\
\text { - Demonstrate personal } \\
\text { and professional } \\
\text { values and their } \\
\text { impact on decision- } \\
\text { making professional } \\
\text { behaviors for } \\
\text { individuals, families, } \\
\text { and populations } \\
\text { across the lifespan } \\
\text { and continuum of } \\
\text { care. (Nursing) }\end{array}$ \\
\hline $\begin{array}{l}\text { Interprofessional } \\
\text { Communication } \\
\text { Communicate with } \\
\text { patients, families, } \\
\text { communities, and } \\
\text { professionals in } \\
\text { health and other } \\
\text { fields in a } \\
\text { responsive and } \\
\text { responsible } \\
\text { manner that } \\
\text { supports a team } \\
\text { approach to the }\end{array}$ & $\begin{array}{l}\text { \#7: Assess } \\
\text { Individuals, } \\
\text { Families, Groups, } \\
\text { Organizations, and } \\
\text { Communities } \\
\text { Social workers } \\
\text { recognize the } \\
\text { implications of the } \\
\text { larger practice } \\
\text { context in the } \\
\text { assessment } \\
\text { process and value } \\
\text { the importance of }\end{array}$ & $\begin{array}{l}\text { 2.3: } \\
\text { Communicates } \\
\text { with respect to } \\
\text { the culture, } \\
\text { socioeconomic } \\
\text { circumstances } \\
\text { and health beliefs } \\
\text { of patients and } \\
\text { families to set } \\
\text { mutual health } \\
\text { goals and provide } \\
\text { services most } \\
\text { likely to benefit } \\
\text { health. }\end{array}$ & $\begin{array}{l}\text { Essential VI: } \\
\text { Interprofessional } \\
\text { Communication } \\
\text { and Collaboration } \\
\text { for Improving } \\
\text { Patient Health } \\
\text { Outcomes. }\end{array}$ & $\begin{array}{l}\text { - Negotiate the social } \\
\text { worker role as part of } \\
\text { a multidisciplinary } \\
\text { team in an integrated } \\
\text { health setting (SW) } \\
\text { - Describe how PAs } \\
\text { function with other } \\
\text { professionals, } \\
\text { including } \\
\text { pharmacists, } \\
\text { registered dieticians, } \\
\text { therapists, social } \\
\text { workers, } \\
\text { chiropractors, }\end{array}$ \\
\hline
\end{tabular}




\begin{tabular}{|c|c|c|c|c|}
\hline $\begin{array}{c}\text { IPEC } \\
\text { Competency \& } \\
\text { Description }\end{array}$ & $\begin{array}{c}\text { EPAS } \\
\text { Competency } \\
\text { (Social Work) }\end{array}$ & PA Competency & $\begin{array}{c}\text { Nursing } \\
\text { Competency }\end{array}$ & $\begin{array}{c}\text { Course Student } \\
\text { Learning Outcomes } \\
\text { (SW, PA \& Nursing) }\end{array}$ \\
\hline $\begin{array}{l}\text { promotion and } \\
\text { maintenance of } \\
\text { health and the } \\
\text { prevention and } \\
\text { treatment of } \\
\text { disease. }\end{array}$ & $\begin{array}{c}\text { interprofessional } \\
\text { collaboration in } \\
\text { this process. }\end{array}$ & & & $\begin{array}{l}\text { doctors of } \\
\text { naturopath, } \\
\text { acupuncturist, and } \\
\text { counselors in health } \\
\text { care environments } \\
\text { and on } \\
\text { interprofessional } \\
\text { teams. (PA) } \\
\text { - Demonstrate } \\
\text { professionalism in } \\
\text { interactions with } \\
\text { faculty and peers. } \\
\text { (PA) } \\
\text { Demonstrate intra- } \\
\text { and inter- professional } \\
\text { communication and } \\
\text { collaboration to } \\
\text { improve the health } \\
\text { outcomes of } \\
\text { individuals, families, } \\
\text { and populations } \\
\text { across the lifespan } \\
\text { and continuum of } \\
\text { care. (Nursing) }\end{array}$ \\
\hline $\begin{array}{l}\text { Teams and } \\
\text { Teamwork } \\
\text { Apply relationship } \\
\text { building values } \\
\text { and the principles } \\
\text { of team dynamics } \\
\text { to perform } \\
\text { effectively in } \\
\text { different team } \\
\text { roles to plan, } \\
\text { deliver, and } \\
\text { evaluate } \\
\text { patient/population } \\
\text { centered care and } \\
\text { population health } \\
\text { programs and } \\
\text { policies that are } \\
\text { safe, timely, } \\
\text { efficient, effective, } \\
\text { and equitable. }\end{array}$ & $\begin{array}{l}\text { \#8: Intervene with } \\
\text { Individuals, } \\
\text { Families, Groups, } \\
\text { Organizations, and } \\
\text { Communities } \\
\\
\text { Social workers } \\
\text { understand } \\
\text { methods of } \\
\text { identifying, } \\
\text { analyzing and } \\
\text { implementing } \\
\text { evidence-informed } \\
\text { interventions to } \\
\text { achieve client and } \\
\text { constituency goals. } \\
\text { Social workers } \\
\text { value the } \\
\text { importance of } \\
\text { interprofessional } \\
\text { teamwork and } \\
\text { communication in } \\
\text { interventions, }\end{array}$ & $\begin{array}{l}\text { 2.1: Demonstrates } \\
\text { professional and } \\
\text { respectful } \\
\text { interactions with } \\
\text { patients, } \\
\text { caregivers and } \\
\text { members of the } \\
\text { interprofessional } \\
\text { team (e.g. peers, } \\
\text { consultants, } \\
\text { nursing, ancillary } \\
\text { professionals and } \\
\text { support } \\
\text { personnel). } \\
2.4 \text { : Works } \\
\text { effectively with } \\
\text { physicians and } \\
\text { other health care } \\
\text { professionals as a } \\
\text { member or leader } \\
\text { of an inter- } \\
\text { professional } \\
\text { health care team }\end{array}$ & $\begin{array}{l}\text { Essential VI: } \\
\text { Interprofessional } \\
\text { Communication } \\
\text { and Collaboration } \\
\text { for Improving } \\
\text { Patient Health } \\
\text { Outcomes. }\end{array}$ & $\begin{array}{l}\text { - Integrate } \\
\text { understandings from a } \\
\text { range of perspectives } \\
\text { in assessing clients } \\
\text { across levels and } \\
\text { fields of practice } \\
\text { (SW) } \\
\text { - Describe how PAs } \\
\text { function with other } \\
\text { professionals, } \\
\text { including } \\
\text { pharmacists, } \\
\text { registered dieticians, } \\
\text { therapists, social } \\
\text { workers, } \\
\text { chiropractors, and } \\
\text { doctors of naturopath, } \\
\text { acupuncturist, and } \\
\text { counselors in health } \\
\text { care environments } \\
\text { and on } \\
\text { interprofessional } \\
\text { teams. (PA) }\end{array}$ \\
\hline
\end{tabular}




\begin{tabular}{|c|c|l|c|c|}
\hline $\begin{array}{c}\text { IPEC } \\
\text { Competency \& } \\
\text { Description }\end{array}$ & $\begin{array}{c}\text { EPAS } \\
\text { Competency } \\
\text { (Social Work) }\end{array}$ & PA Competency & $\begin{array}{c}\text { Nursing } \\
\text { Competency }\end{array}$ & $\begin{array}{c}\text { Course Student } \\
\text { Learning Outcomes } \\
\text { (SW, PA \& Nursing) }\end{array}$ \\
\hline & $\begin{array}{c}\text { recognizing that } \\
\text { beneficial } \\
\text { outcomes may } \\
\text { require } \\
\text { interdisciplinary, } \\
\text { interprofessional, } \\
\text { and inter- } \\
\text { organizational } \\
\text { collaboration. }\end{array}$ & $\begin{array}{l}\text { or other } \\
\text { professional } \\
\text { group. }\end{array}$ & & $\begin{array}{c}\text { Apply the nursing } \\
\text { process to improve } \\
\text { health outcomes for } \\
\text { individuals, families, } \\
\text { \& populations across } \\
\text { the lifespan \& } \\
\text { continum of care. } \\
\end{array}$ \\
& & & (Nursing) \\
\hline
\end{tabular}

\section{THE HYBRID EXPERIENCE}

The IPE hybrid experience provided participating students the opportunity to foster interdisciplinary collaboration, forging relationships to engage in a dynamic healthcare system with a collaborative approach to care. The three participating programs delivered IPE learning activities in three stages: a recorded interdisciplinary case presentation, an interactive interprofessional face-to-face class, and an online student-learning module through the LMS. The hybrid experience was designed to enhance student understanding of interprofessional communication and teamwork through face-to-face and online learning opportunities.

\section{Collaborative Case Dissuasion}

As part of the course module, a panel session was initiated with faculty from the three programs to demonstrate interprofessional collaboration on a patient care scenario. The recording panel session was uploaded to the LMS for the students to refer to as an example of best care practices for improving patient access and healthcare outcomes from a collaborative client care perspective. The mock presentation also modeled professional strengths and collaborative engagement in client assessment and intervention planning from a bio-psycho-social-cultural perspective.

\section{Face-To-Face Session}

The first meeting of students from all three programs was planned to introduce students to meet each other and to provide an overview of the roles, responsibilities, and practice guidelines of the three professions. The face-to-face session also facilitated team building activities with interprofessional groups. The intent of the live session was to introduce students to each other, and provide an overview of each profession to create an environment in accordance with the World Health Organization (WHO) definition of IPE, "to learn about, from, and with each other" (World Health Organization [WHO], 2010, 13). The face-to-face session began with an ice-breaker exercise, which helped to build rapport, foster new relationships, and break down traditional education silos. Finally, the session provided an overview of course expectations, timelines for assignments, and discussion of the ultimate goal of the face-to-face online modality.

\section{Online Course Structure}

In an effort to address scheduling conflicts for various programs, faculty collaborated with the Office of Teaching and Learning Technologies (TLT) at the University to develop an online course shell to ensure students from all programs were included in the interprofessional module. The TLT administrator had the capability (with faculty permission) to include all students from the three courses in the course shell. All participating faculty and students were included in the course shell to facilitate communication, as well as participate in and complete the group activities and group discussions planned for the module. 
All instructional material related to the IPE module and participating professions were uploaded to a resource tab to ensure all students had access.

\section{IPE Hybrid Modality Composition IPE Online Team Building}

The creation of IPE discussion groups facilitated student engagement in an active discussion about the case scenario that was parallel to the face-to face-class discussion. Interprofessional workgroups were created by the instructors to support the hybrid learning opportunity. Participants were queried about their availability, and then workgroups were created to match the availability of the students. The workgroups were balanced by the instructors to ensure adequate representation from each discipline. These workgroups were maintained throughout the hybrid experience. Formal introductions and establishment of the groups occurred during the face-to-face class.

Eight groups were created to ensure manageable group participation. Varying class requirements, including work and personal schedules and commitments, were taken into account in the identification of the workgroups. Students were asked to present their availability for group selection. Utilizing the following scheduling choices, "flexible schedule," "available weekends," "available during the day," and "available evening" allowed for group assembly.

Workgroup formation also supported opportunities for students to identify means of communication best suited to their team working relationship. Students were encouraged to exchange phone numbers, coordinate meeting times, and/or discuss the case scenario in the most convenient modality for them. Students were required to meet at least twice as a group through their preferred means to discuss about the case scenario, and work as an interprofessional team to answer the questions posed at the end of the case scenario.

\section{Case Scenario}

According to the Nevada Opiate Crisis Needs Assessment, Nevada ranked 13th in opioid painkiller prescribing rates in 2016 (Nevada Department of Health \& Human Services [NVDHHS], 2018). This needs assessment outlines the importance of funding an interprofessional workforce to combat the opiate crisis, which helps to illustrate care gaps that exist especially in Nevada's rural and frontier communities (NVDHHS, 2018). The Nevada Legislature successfully passed legislation in 2015 and 2017 to address these gaps, and promote an interprofessional approach to care. With the implementation of this legislation, the opioid-related overdose rate in Nevada has been lower than the U.S. rate for the past four years (Bekker, 2018). There has been a 22\% decrease in overdose-related deaths since 2011, and a $6 \%$ decrease in overdose-related deaths since 2015 (Bekker, 2018).

Given the national opioid epidemic, coupled with the need to build a workforce trained to address the needs in rural and frontier areas in Nevada, the IPE case example selected seemed appropriate at the time of course delivery. The IPE team identified a case study describing a young pregnant woman, who was struggling with a number of mental health issues, one of which was an addiction to opiates (Appendix A). Opiate addiction was also selected as a fundamental component of the case study, as caring for individuals who are dealing with addiction requires an interprofessional approach to ensure successful outcomes.

Based on the case example, the IPE team faculty developed questions (Appendix B) that encompassed education opportunities for each profession. These questions served as discussion prompts for students to engage in dialogue, which helped to ensure that all students had an active role in the assessment and collaborative intervention planning for the patient. The case scenario, along with discussion questions, was posted in the online learning module. The students were asked to review and reflect on the questions individually, as well as in their IPE groups. This fostered an introspective review of a hypothetical case scenario and fostered a collaborative care approach. Based on group discussions, questions related to the case scenario questions were answered, and submitted to the LMS system. 


\section{IPE Case Reflection}

To further highlight the four IPEC competencies, students were asked to write a brief reflection paper outlining their participation in the IPE hybrid model. The reflection paper allowed students to demonstrate their respective experience working with an interdisciplinary team, as well as develop a plan for further collaborative growth. Each student submitted a reflection based on their individual engagement, assessment, and evaluation of the roles and interactions in the team-based learning, both online and face-to-face. Students were encouraged to reflect on the IPE process, and to suggest their recommendation for future practice enhancements.

\section{Mastery of Competency Measurement}

The IPE faculty team aimed to evaluate the impact of infusing IPE in a hybrid experience in an attempt to measure mastery of IPEC competencies (Sanborn, 2016). The ICCAS scale is a valid and reliable self-assessment instrument, intended to measure mastery of domains of interprofessional collaboration competencies. The IPE competency domains include communication, collaboration, roles and responsibilities, patient/family centered-care, conflict management/resolution, and team functioning. While ICCAS measures outcomes based on self-evaluation, it also allows participants to rate their own mastery of competency in the IPE experience. The use of ICCAS represents the IOM recommendation of standard implementation to educational settings.

Faculty sought Institutional Review Board (IRB) approval from the University of Nevada IRB. Students willing to have their competency measured during the IPE hybrid model experience gave informed consent using an IRB-approved form.

\section{IPE HYBRID MODEL RESULTS \& DISCUSSION}

Of the 70 students who participated in the hybrid experience, 53 consented to participate in the evaluation and completed the ICCAS survey. Students, who consented to participate in the evaluation, completed two surveys related to their professional characteristics and experience. These surveys provided perspective to the students' healthcare experience and exposure to interprofessional teams, as compared to the ICCAS tool, which was used to evaluate the use of core constructs in interprofessional education and collaboration in this IPE experience. A paired samples t-test was conducted using SPSS Version 24 to determine whether the self-measured competencies changed after the implementation of IPE hybrid education. The mean scores before and after the experience, as well as the difference in mean scores before and after the experience were included in the analysis. The standard deviation, degrees of freedom, t-values, and p-values were also computed in the data summary.

\section{Student Characteristics Data}

Table 2 demonstrates the students' response to eight questions designed to determine characteristics of the group's professional background, while Table 3 breaks down these student characteristics by program. The collected data revealed a wide variety of experience and exposure to interprofessional collaboration, regardless of program type. The data presented in Table 3 was utilized to provide context for the IPE experience, as most students demonstrated previous or current experience working with interprofessional teams. As healthcare providers are the sum of their experiences, it is important to understand experience in relation to preconceived notions regarding interprofessional work. These demographics also provide a depth to the ICCASS survey results, where students are applying their knowledge and experience to their current educational endeavors.

As depicted in Table 2, approximately $43 \%$ of students that participated were enrolled in the physician assistant program, $28 \%$ of survey respondents each were from social work and the nursing program. About $72 \%$ of students responded that they had worked in a paid healthcare setting, while $27 \%$ stated that they currently work in such a setting. The number of hours worked in a healthcare setting varied. About $26 \%$ of respondents reported having never worked with other professionals, with $46 \%$ of respondents reporting that they had worked in a setting with interprofessional exposure. Survey results were diversely represented by program, as represented in Table 3. 
At the time of the IPE hybrid education, about $52 \%$ of students were currently placed in fieldwork in an internship, with all students that were placed in fieldwork working with other professionals in their field of placement. Approximately $36 \%$ of students reported participation in routine clinical meetings with other professionals or huddles.

While the cumulative nature of the collected data is not correlated to existing research on the make-up of IPE activities, it demonstrates the diversity in exposure to healthcare experience and interprofessional collaboration among the three programs participating in the hybrid IPE experience. This provides an additional layer to the pre-experience ICCAS survey data, as correlated to the post-experience data.

TABLE 2

\section{STUDENT CHARACTERISTICS}

\begin{tabular}{|c|c|c|}
\hline Variable & $\mathbf{N}$ & $\%$ \\
\hline \multicolumn{3}{|l|}{ Profession $(N=53)$} \\
\hline Social Worker & 15 & $28.3 \%$ \\
\hline Physician Assistant & 23 & $43.4 \%$ \\
\hline Nurse & 15 & $28.3 \%$ \\
\hline \multicolumn{3}{|l|}{ Ever worked in paid healthcare setting ( $N=53)$} \\
\hline Yes & 38 & $71.7 \%$ \\
\hline No & 15 & $28.3 \%$ \\
\hline \multicolumn{3}{|l|}{ Hours worked in a healthcare setting $(N=53)$} \\
\hline$<2$ years & 12 & $22.6 \%$ \\
\hline 2 to 4 years & 5 & $9.4 \%$ \\
\hline 4 to 6 years & 12 & $22.6 \%$ \\
\hline 6 to 10 years & 5 & $9.4 \%$ \\
\hline $10+$ years & 5 & $9.4 \%$ \\
\hline Did not work in a healthcare setting & 14 & $26.4 \%$ \\
\hline \multicolumn{3}{|l|}{ Currently working in a paid position $(N=53)$} \\
\hline Yes & 14 & $26.9 \%$ \\
\hline No & 38 & $74.1 \%$ \\
\hline Missing & 1 & \\
\hline \multicolumn{3}{|c|}{ Worked with other professionals in paid position $(N=53)$} \\
\hline Yes & 39 & $73.6 \%$ \\
\hline No & 14 & $26.4 \%$ \\
\hline \multicolumn{3}{|c|}{$\begin{array}{l}\text { Currently placed in an agency for internship/field placement } \\
(N=53)\end{array}$} \\
\hline Yes & 27 & $51.9 \%$ \\
\hline No & 25 & $48.1 \%$ \\
\hline Missing & 1 & \\
\hline \multicolumn{3}{|c|}{$\begin{array}{l}\text { Engaged with other professionals in internship/field placement } \\
(N=53)\end{array}$} \\
\hline Yes & 27 & $50.9 \%$ \\
\hline No & 2 & $3.8 \%$ \\
\hline Was not placed in agency for field placement & 24 & $45.3 \%$ \\
\hline \multicolumn{3}{|c|}{ Participated in huddles or other routine clinical meetings $(N=53)$} \\
\hline Yes & 19 & $35.8 \%$ \\
\hline No & 11 & $20.8 \%$ \\
\hline Was not placed in agency for field placement & 23 & $43.4 \%$ \\
\hline
\end{tabular}


TABLE 3

CHARACTERISTICS OF STUDENTS BY TYPE OF PROGRAM

\begin{tabular}{|c|c|c|c|c|c|c|}
\hline \multirow[t]{2}{*}{ Variable } & \multicolumn{2}{|c|}{$\begin{array}{c}\text { Nursing } \\
(\mathbf{N}=15)\end{array}$} & \multicolumn{2}{|c|}{$\begin{array}{c}\text { Physician } \\
\text { Assistant } \\
(\mathbf{N}=\mathbf{2 3})\end{array}$} & \multicolumn{2}{|c|}{$\begin{array}{l}\text { Social Work } \\
\quad(\mathbf{N}=15)\end{array}$} \\
\hline & $\mathbf{N}$ & $\%$ & $\mathbf{N}$ & $\%$ & $\mathbf{N}$ & $\%$ \\
\hline \multicolumn{7}{|l|}{ Ever worked in paid healthcare setting ( $N=53)$} \\
\hline Yes & 9 & 17.0 & 23 & 43.4 & 6 & 11.3 \\
\hline No & 6 & 11.3 & 0 & 0.0 & 9 & 17.0 \\
\hline \multicolumn{7}{|l|}{ Role in healthcare setting* } \\
\hline Tech & 0 & 0.0 & 16 & 30.2 & 0 & 0.0 \\
\hline N/A & 5 & 9.4 & 0 & 0.0 & 9 & 17.0 \\
\hline Nurse Apprentice & 8 & 15.1 & 0 & 0.0 & 0 & 0.0 \\
\hline Physical therapy aide & 0 & 0.0 & 3 & 5.7 & 0 & 0.0 \\
\hline Scribe & 0 & 0.0 & 3 & 5.7 & 0 & 0.0 \\
\hline CAN & 0 & 0.0 & 3 & 5.7 & 0 & 0.0 \\
\hline \multicolumn{7}{|l|}{ Hours worked in a healthcare setting ( $N=53)$} \\
\hline$<2$ years & 9 & 17.0 & 0 & 0.0 & 3 & 5.7 \\
\hline 2 to 4 years & 1 & 1.9 & 3 & 5.7 & 1 & 1.9 \\
\hline 4 to 6 years & 0 & 0.0 & 11 & 20.8 & 1 & 1.9 \\
\hline 6 to 10 years & 0 & 0.0 & 5 & 9.4 & 0 & 0.0 \\
\hline $10+$ years & 0 & 0.0 & 4 & 7.5 & 1 & 1.9 \\
\hline Did not work in a healthcare setting & 5 & 9.4 & 0 & 0.0 & 9 & 17.0 \\
\hline \multicolumn{7}{|c|}{ Worked with other professionals in paid position ( $N=53$ ) } \\
\hline Yes & 10 & 18.9 & 23 & 43.4 & 6 & 11.3 \\
\hline No & 5 & 9.4 & 0 & 0.0 & 9 & 17.0 \\
\hline \multicolumn{7}{|c|}{$\begin{array}{l}\text { Currently placed in an agency for internship/field placement } \\
(N=52)\end{array}$} \\
\hline Yes & 15 & 28.8 & 2 & 3.8 & 10 & 19.2 \\
\hline No & 0 & 0.0 & 21 & 40.4 & 4 & 7.7 \\
\hline Missing & & & & & 1 & \\
\hline \multicolumn{7}{|l|}{$\begin{array}{l}\text { Engaged with other professionals in internship/field } \\
\text { placement }(N=53)\end{array}$} \\
\hline Yes & 14 & 26.4 & 2 & 3.8 & 11 & 20.8 \\
\hline No & 1 & 1.9 & 0 & 0.0 & 1 & 1.9 \\
\hline Was not placed in agency for field placement & 0 & 0.0 & 21 & 39.6 & 3 & 5.7 \\
\hline \multicolumn{7}{|l|}{ Professionals usually worked with* } \\
\hline N/A & 1 & 1.9 & 21 & 39.6 & 3 & 5.7 \\
\hline Physician & 12 & 22.6 & 2 & 3.8 & 10 & 18.9 \\
\hline Nurse & 6 & 11.3 & 1 & 1.9 & 4 & 7.5 \\
\hline Social Worker & 8 & 15.1 & 0 & 0.0 & 3 & 5.7 \\
\hline Psychologist & 1 & 1.9 & 0 & 0.0 & 4 & 7.5 \\
\hline Respiratory Therapist & 5 & 9.4 & 0 & 0.0 & 0 & 0.0 \\
\hline \multicolumn{7}{|c|}{$\begin{array}{l}\text { Participated in huddles or other routine clinical meetings } \\
(N=53)\end{array}$} \\
\hline Yes & 11 & 20.8 & 2 & 3.8 & 6 & 11.3 \\
\hline No & 4 & 7.5 & 1 & 1.9 & 6 & 11.3 \\
\hline Was not placed in agency for field placement & 0 & 0.0 & 20 & 37.7 & 3 & 5.7 \\
\hline
\end{tabular}

* Professionals could have had multiple prior roles or worked with multiple professionals. Percentages were calculated based on the total number of professionals $(\mathrm{N}=53)$. 


\section{ICCAS Data}

As collaborative environments foster discovery and innovation across disciplines, IPE activities are designed to support and enhance scholarly and scientific endeavors. The hybrid learning experience developed through this study was an active learning process to provide students time and resources to describe the various roles of other healthcare professionals. This experience also allowed for the application of team-based patient care, which incorporated the concepts of team dynamics in healthcare delivery systems. This experience provided students the opportunity to understand the foundations and domains of interprofessional education, as identified through the ICCAS survey, which will enhance the student's ability to communication and augment their role collaboration (Wong, Leslie, Soon, \& Norman, 2016).

The results of the ICCAS survey are shown in Table 4. There were 20 ICCAS competencies assessed before instituting IPE hybrid education and after IPE hybrid education. All competency responses exhibited an increase from before the IPE experience was implemented, as compared to after IPE was implemented. The difference in means between pre- and post- scores ranged from an increase of 0.47 to an increase of 1.08. This demonstrates a significant improvement in the self-assessed understanding of IPE over the course of the hybrid experience. Table 5 highlights a paired samples t-test, which compared pre- and post-test means of the ICCAS surveys. This table illustrate a statistically significant improvement in the self-reported understanding and application gained through the IPE experience.

Of note, the data suggests that students felt their greatest improvement gained through the experience was the ability to develop an effective care plan with interprofessional team members, as well as the utilization of interprofessional team members to address complex health needs despite the varying group discussion communication preference. The data also suggests that, as a result of the IPE experience, students grew in their understanding of the abilities and contributions of IP team members, as well as how to recognize how interprofessional team members' skills and knowledge could complement and overlap with their own knowledge and experience. These results demonstrate the effectiveness of the IPE experience, as well as the growth students expressed as a result of working in an interprofessional teams, highlighting the benefit of IPE opportunities gained through non-traditional teaching modalities. Conversely, students reflected that hybrid IPE experience did not improve their understanding or utilization of IPE to enhance the inclusion of the patient/family in the decision-making process. Although this was not an intended focus of the hybrid experience, it highlights an area for improvement in future hybrid IPE experiences. 
TABLE 4

ICCAS COMPETENCY PRE/POST IPE HYBRID EDUCATION MEAN SCORES

\begin{tabular}{|c|c|c|c|c|}
\hline Competency & $\mathbf{N}$ & $\begin{array}{l}\text { Pre Score } \\
\text { Mean }\end{array}$ & $\begin{array}{l}\text { Post Score } \\
\text { Mean }\end{array}$ & Difference \\
\hline $\begin{array}{l}\text { Promote effective communication among } \\
\text { members of an IP team }\end{array}$ & 53 & 3.45 & 4.08 & 0.63 \\
\hline $\begin{array}{l}\text { Actively listen to IP members' ideas and } \\
\text { concerns. }\end{array}$ & 53 & 3.83 & 4.51 & 0.68 \\
\hline $\begin{array}{l}\text { Express my ideas and concerns without being } \\
\text { judgmental. }\end{array}$ & 53 & 3.72 & 4.30 & 0.58 \\
\hline $\begin{array}{l}\text { Provide constructive feedback to IP team } \\
\text { members. }\end{array}$ & 53 & 3.13 & 3.94 & 0.81 \\
\hline Express my ideas in a clear, concise manner. & 53 & 3.49 & 4.13 & 0.64 \\
\hline Seek out IP team members to address issues. & 53 & 3.02 & 4.08 & 1.06 \\
\hline Work effectively with IP team to enhance care. & 52 & 3.46 & 4.35 & 0.89 \\
\hline $\begin{array}{l}\text { Learn with, from, and about IP team members to } \\
\text { enhance care. }\end{array}$ & 52 & 3.62 & 4.35 & 0.73 \\
\hline $\begin{array}{l}\text { Identify and describe my abilities and } \\
\text { contributions to the IP team. }\end{array}$ & 53 & 3.42 & 4.15 & 0.73 \\
\hline $\begin{array}{l}\text { Be accountable for my contributions on the IP } \\
\text { team. }\end{array}$ & 53 & 3.74 & 4.36 & 0.62 \\
\hline $\begin{array}{l}\text { Understand the abilities and contributions of IP } \\
\text { team members. }\end{array}$ & 53 & 3.21 & 4.17 & 0.96 \\
\hline $\begin{array}{l}\text { Recognize how others' skills and knowledge } \\
\text { complement and overlap with my own. }\end{array}$ & 53 & 3.32 & 4.26 & 0.94 \\
\hline $\begin{array}{l}\text { Use an IP team approach with the patient to } \\
\text { assess the health situation. }\end{array}$ & 53 & 3.21 & 4.17 & 0.96 \\
\hline $\begin{array}{l}\text { Use an IP team approach with the patient to } \\
\text { provide whole person care. }\end{array}$ & 53 & 3.23 & 4.09 & 0.86 \\
\hline Include the patient/family in decision-making. & 52 & 3.63 & 4.10 & 0.47 \\
\hline $\begin{array}{l}\text { Actively listen to the perspectives of IP team } \\
\text { members. }\end{array}$ & 53 & 3.87 & 4.51 & 0.64 \\
\hline Take into account the ideas of IP team members. & 53 & 3.77 & 4.49 & 0.72 \\
\hline Address team conflict in a respectful manner. & 52 & 3.60 & 4.27 & 0.67 \\
\hline $\begin{array}{l}\text { Develop an effective care plan with IP team } \\
\text { members. }\end{array}$ & 53 & 3.26 & 4.34 & 1.08 \\
\hline $\begin{array}{l}\text { Negotiate responsibilities within overlapping } \\
\text { scopes of practice. }\end{array}$ & 53 & 3.36 & 4.32 & 0.96 \\
\hline
\end{tabular}


TABLE 5

RESULTS OF PAIRED SAMPLES T-TEST ON PRE/POST ICCAS SCORES

\begin{tabular}{|c|c|c|c|c|c|c|}
\hline Competency & $\mathbf{N}$ & Mean & SD & t-value & df & p-value \\
\hline $\begin{array}{l}\text { Promote effective communication } \\
\text { among members of an IP team }\end{array}$ & 53 & 0.63 & 0.74 & 6.13 & 52 & $<.001$ \\
\hline $\begin{array}{l}\text { Actively listen to IP members' ideas and } \\
\text { concerns. }\end{array}$ & 53 & 0.68 & 0.78 & 6.35 & 52 & $<.001$ \\
\hline $\begin{array}{l}\text { Express my ideas and concerns without } \\
\text { being judgmental. }\end{array}$ & 53 & 0.58 & 0.69 & 6.16 & 52 & $<.001$ \\
\hline $\begin{array}{l}\text { Provide constructive feedback to IP } \\
\text { team members. }\end{array}$ & 53 & 0.81 & 0.71 & 8.34 & 52 & $<.001$ \\
\hline $\begin{array}{l}\text { Express my ideas in a clear, concise } \\
\text { manner. }\end{array}$ & 53 & 0.64 & 0.74 & 6.34 & 52 & $<.001$ \\
\hline $\begin{array}{l}\text { Seek out IP team members to address } \\
\text { issues. }\end{array}$ & 53 & 1.06 & 0.97 & 7.94 & 52 & $<.001$ \\
\hline $\begin{array}{l}\text { Work effectively with IP team to } \\
\text { enhance care. }\end{array}$ & 52 & 0.89 & 0.92 & 6.92 & 51 & $<.001$ \\
\hline $\begin{array}{l}\text { Learn with, from, and about IP team } \\
\text { members to enhance care. }\end{array}$ & 52 & 0.73 & 0.89 & 5.93 & 51 & $<.001$ \\
\hline $\begin{array}{l}\text { Identify and describe my abilities and } \\
\text { contributions to the IP team. }\end{array}$ & 53 & 0.73 & 0.84 & 6.41 & 52 & $<.001$ \\
\hline $\begin{array}{l}\text { Be accountable for my contributions of } \\
\text { the IP team. }\end{array}$ & 53 & 0.62 & 0.77 & 5.92 & 52 & $<.001$ \\
\hline $\begin{array}{l}\text { Understand the abilities and } \\
\text { contributions of IP team members. }\end{array}$ & 53 & 0.96 & 1.04 & 6.76 & 52 & $<.001$ \\
\hline $\begin{array}{l}\text { Recognize how others' skills and } \\
\text { knowledge complement and overlap } \\
\text { with my own. }\end{array}$ & 53 & 0.94 & 0.99 & 6.95 & 52 & $<.001$ \\
\hline $\begin{array}{l}\text { Use an IP team approach with the } \\
\text { patient to assess the health situation. }\end{array}$ & 53 & 0.96 & 0.85 & 8.20 & 52 & $<.001$ \\
\hline $\begin{array}{l}\text { Use an IP team approach with the } \\
\text { patient to provide whole person care. }\end{array}$ & 53 & 0.86 & 0.90 & 7.02 & 52 & $<.001$ \\
\hline $\begin{array}{l}\text { Include the patient/family in decision- } \\
\text { making. }\end{array}$ & 52 & 0.47 & 0.83 & 4.02 & 51 & $<.001$ \\
\hline $\begin{array}{l}\text { Actively listen to the perspectives of IP } \\
\text { team members. }\end{array}$ & 53 & 0.64 & 0.71 & 6.58 & 52 & $<.001$ \\
\hline $\begin{array}{l}\text { Take into account the ideas of IP team } \\
\text { members. }\end{array}$ & 53 & 0.72 & 0.84 & 6.21 & 52 & $<.001$ \\
\hline $\begin{array}{l}\text { Address team conflict in a respectful } \\
\text { manner. }\end{array}$ & 52 & 0.67 & 0.73 & 6.62 & 51 & $<.001$ \\
\hline $\begin{array}{l}\text { Develop an effective care plan with IP } \\
\text { team members. }\end{array}$ & 53 & 1.08 & 1.04 & 7.57 & 52 & $<.001$ \\
\hline $\begin{array}{l}\text { Negotiate responsibilities within } \\
\text { overlapping scopes of practice. }\end{array}$ & 53 & 0.96 & 0.90 & 7.80 & 52 & $<.001$ \\
\hline
\end{tabular}

\section{FUTURE IMPLICATIONS \& RECOMMENDATIONS}

Online learning is emerging as a way to overcome pedagogical barriers and silos present in various educational programs (McPherson et al., 2001). Online learning can also alleviate scheduling conflicts and differing course requirements. However, a course with no face-to-face interaction can also have its 
own challenges and pitfalls. Learner isolation continues to be a concern, and is especially problematic for learners who appreciate the nuances that are recognized in face-to-face interaction and real-time discussions. In order to address these concerns, the IPE hybrid modality was created to infuse an IPE module into existing courses. Feedback from the students indicated that while the hybrid modality was useful in coordinating scheduling, anecdotally students felt the richest interaction occurred in the face-toface meetings. Combining pedagogy for IPE into an online and in-person educational delivery modality may prove to be both efficient and effective

Based on lessons learned from this exercise, for the first introductory session with students and faculty from all disciplines, it would be beneficial to include some videoconferencing technologies to create an opportunity for students who could not join in the face-to-face session. Such technology would provide opportunities to engage students in hybrid modalities to maximize educational opportunities. Including such technology could enhance engagement, which could also prepare future healthcare professionals if they were to pursue telehealth-related work for clients in rural areas. As IPE fosters collaborative practice, such newer learning experiences could help students prepare healthcare professionals to think beyond the typical service delivery modalities in a clinic.

To ensure continued evaluation of the growth utilizing a hybrid IPE experience, students should be tested following future IPE educational experiences to determine if repeated exposure improves their ability to work in a collaborative team utilizing a hybrid experience. This should also be compared to the traditional face-to-face and strict online delivery methods, as well as teaching modalities that blend faceto-face instruction with the use of LMS instruction and video conferencing opportunities.

\section{STUDY LIMITATIONS}

The ICCAS has a final question related to overall learning and mastery of IPE competency. One of the limitations of the study is the lack of response from students on the final question. Only 14 students (26\%) responded to the final question comparing their interprofessional competency before and after the IPE activity, hence data related to that question is not included in the paper. Future use of the ICCAS survey would need to ensure special notation regarding student response to the final question. Another limitation of the study was the use of ICCAS as a measurement of competency since students were completing a self-evaluation. Direct objective observation of the interprofessional student interaction would further correlate a change in interprofessional learning and collaboration.

\section{CONCLUSION}

This hybrid IPE experience attempted to reduce educational isolation in the healthcare disciplines through communication, collaboration, and effective team-oriented environments. It created an avenue for students to foster relationships, which will hopefully enhance the dynamics of healthcare teams in the future. The results of the ICCAS survey following the IPE activity provided students the opportunity to reflect on their own personal growth. Self-reflection is an essential component in the development of professional identity in the mastery of team-based service delivery approaches. The study demonstrated significance in this respect, which will prepare these students to enter healthcare systems as a collaborative team member striving to improve healthcare outcomes across the continuum. This experience allowed students to transcend traditional educational boundaries through a hybrid experience, promoting unique efforts to enhance collaborative educational experiences.

\section{REFERENCES}

Bekker, J. (2018, September 30). Nevada again lands at bottom of national health-care ranking. Las Vegas Review-Journal. Retrieved from https://www.reviewjournal.com/life/health/nevada-again-landsat-bottom-of-national-health-care-ranking/ 
Blue, A.V., Charles, L., Howell, D., Koutalos, Y., Mitcham, M., Nappi, J., \& Zoller, J. (2010). Introducing students to patient safety through an online interprofessional course. Advanced Medical Education Practice, 1, 107-14. https://doi.org/.10.2147/AMEP.S13350

Bridges, D. R., Davidson, R. A., Odegard, P. S., Maki, I. V., \& Tomkowiak, J. (2011). Interprofessional collaboration: Three best practice models of interprofessional education. Medical Education Online, 16(1), 6035. doi: 10.3402/meo.v16i0.6035

Collins, A., Broeseker, A., Cunningham, J., Cortes, C., Beall, J., Bigham, A., \& Chang, J. (2017). A longitudinal online interprofessional education experience involving family nurse practitioner students and pharmacy students. Journal of Interprofessional Care, 31(2), 218-225. doi: 10.1080/13561820.2016.1255600.

De Los Santos, M., McFarlin, D.C., \& Martin, L. (2014). Interprofessional education and service learning: A model for the future of health professions education. Journal of Interprofessional Care, 28(4), 374-375. http://dx.doi.org/10.3109/13561820.2014.889102

Fowler, T., Phillips, S., Patel, S., Ruggiero, K., Ragucci, K., Kern, D., \& Stuart, G. (2018). Virtual interprofessional learning. Journal of Nursing Education, 57(11), 668-674. https://doi.org/10.3928/01484834-20181022-07

Interprofessional Education Collaborative. (2018). What is interprofessional education (IPE)? Retrieved from https://www.ipecollaborative.org/about-ipec.html

Institute of Medicine. (2001). Crossing the quality chasm: A new health care system for the 21 st century. Washington, DC: National Academy Press.

Institute of Medicine. (2010). The future of nursing leading change: Focus on scope of practice. Washington, DC: National Academy Press.

Kilgore W., \& Lowenthal, P. (2017). The human element MOOC. In Management Association (Eds.), Blended learning: Concepts, methodologies, tools, and applications (pp. 1736-1751). IGI Global: United States.

McKenna, L., Boyle, M., Palermo, C., Molloy, E., Williams, B., \& Brown, T. (2014). Promoting interprofessional understanding through online learning: A qualitative examination. Nursing Health Science, 16(3), 321-6. doi: 10.1111/nhs. 12105

McPherson, K., Headrick, L., \& Moss, F. (2001). Working and learning together: Good quality care depends on it, but how can we achieve it? Quality Health Care, 10(Suppl 2), ii46-53. doi: 10.1136/qhc. 0100046

Nevada Department of Health \& Human Services. (2018). Nevada opioid crisis needs assessment. Retrieved from http://dpbh.nv.gov/uploadedFiles/dpbhnvgov/content/Resources/opioids/DHHSdata/NevadaOpioidCrisisNeedsAssessment061818.pdf

Reeves, S., Fletcher, S., McLoughlin, C., Yim, A., \& Patel, K.D. (2017, August). Interprofessional online learning for primary healthcare: Findings from a scoping review. BMJ Open, 7(8), e016872. doi: 10.1136/bmjopen-2017-016872

Sanborn, H. (2016). Developing asynchronous online interprofessional education. Journal of Interprofessional Care, 30(5), 668-70. doi: 10.1080/13561820.2016

Simpson, D., Fenzel, J., Rehm, J., \& Marcdante, K. (2010). Enriching educators' repertoire of appropriate instructional methods. The Journal of Teaching and Learning Resources. https://doi.org/10.15766/mep_2374-8265.7968

The American Association of Colleges of Nursing. (2008). Interdisciplinary education and practice. Retrieved from https://www. aacnnursing.org/News-Information/Position-Statements-WhitePapers/Interdisciplinary-Education-Practice

Wong, E., Leslie, J. J., Soon, J. A., \& Norman, W. V. (2016). Measuring interprofessional competencies and attitudes among health professional students creating family planning virtual patient cares. BMC Medical Education, 16(1), 273. https://doi.org/10.1186/s12909-016-0797-8

World Health Organization. (2010). Framework for action on interprofessional education and collaborative practice. Retrieved from https://apps.who.int/iris/bitstream/handle/10665/70185/WHO_HRH_HPN_10.3_eng.pdf;jsessioni

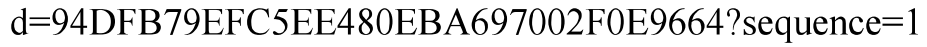




\section{APPENDIX A}

\section{INTERDISCIPLINARY CASE STUDY}

\section{Case Study - Suzanne S.}

Suzanne is a 22-year old single woman, who has been living with her boyfriend Jack in Reno, NV for the last two years. They both have recently become heroin addicts.

Suzanne and Jack met in high school. Suzanne was in a terrible car accident her senior year in high school. She sustained injuries to her back, which left her with severe, chronic lower back pain. She was seen by several specialists, and prescribed OxyContin for her pain. After two years of being on OxyContin, her medication was changed to OxyContin 80mg BID with Norco 10mg q 6hrs as needed for breakthrough pain. She was also prescribed several muscle relaxers to use as needed. She began overusing the medication because it gave her "energy," and "blocked out all the noise and pain."

Both Jack and Suzanne started experimenting with the medication, and began using it recreationally. Suzanne would run out of her medication, and seek early refills from her prescribing PA. She also started frequenting the local emergency departments and urgent cares to seek additional prescriptions. Suzanne would even ask her high-school aged sister to pill shop. If her sister refused or was unsuccessful, Suzanne's reactions would be violent, or she would cry for hours. Her PA eventually ran a medication report through the Prescription Monitoring Program (PMP), as recently required by law, and found that Suzanne had been receiving medications from a number of providers in town. When the PA confront Suzanne, she became erratic, and stormed out of the office. Suzanne was fired from the practice, and was not allowed to continue to see the PA for care.

Suzanne found herself without a source to get her "fix," as her sister has been refusing to lie for her as well. This chain of events led Suzanne to the streets. OxyContin and synthetic opiates proved to be too expensive to purchase from local dealers. Suzanne and Jack left home, and started living together in a small apartment downtown, but found it hard to make rent. They were approached by friends to try heroin because it was so inexpensive. This led to them using heroin regularly. Suzanne's' sister continue to visit their apartment.

Friends and family had not heard from Suzanne and Jack for several days. Paramedics were called to their apartment on Sunday, where they found Suzanne lying on the floor, unresponsive. Jack was not home at the time. At the scene, Suzanne's vitals were as follows:

- $\quad \mathrm{BP}-84 / 60$

- HR 104

- $\mathrm{R}-8$ \& shallow

- Glasgow Coma Score - 3

- Blood glucose - 45

The patient's pupils were constricted and non-reactive. Her skin was cool and cyanotic. Paramedics were able to establish an IV. They provided her an amp of D50, and administered a total of $5.2 \mathrm{mg}$ of Narcan in route to the hospital. Upon triage at the hospital, the patient's vital signs were as follows:

- Temperature - 97.4 F

- $\mathrm{HR}-111$

- $\mathrm{R}-24$

- $\mathrm{BP}-117 / 88$

- $\mathrm{SpO} 2-98 \% \mathrm{RA}$

- Blood glucose - 40

Suzanne was able to answer questions, but still appear very lethargic. Suzanne denied any symptoms, and state she was not sure why she had been brought to the ED. She denied any previous medical problems, and could not remember any current medications she was taking. She was admitted to the observation unit for further medical evaluation. After another day in the hospital, she was discharged home. 
Several months after the hospitalization, Suzanne presented to the free "drop-in" counseling clinic to get some information and advice. She indicated that she and Jack were struggling. They were soon to be evicted from their apartment, and Jack had recently lost his job. His drug use was escalating, and she notes that he has become very depressed. Suzanne states that she stays up all night, unable to focus on anything of importance. She then notes that she will "crash," and sleep for days on end. She also reports that she has had to "turn a couple of tricks" (without Jack's knowledge) to get money for drugs. She is obsessively worried that Jack might find out

During the conversation, Suzanne reports that when she was 10-years old, her father, who was always a heavy drinker, lost his job. Things were tough. Her mother was always working, and she had to take care of her younger siblings. At 14, Suzanne started drinking and smoking marijuana to calm her mind. Suzanne states that she was a good kid, and did pretty well in school. She was able to study all night for long stretches. She wanted to go to college. She does not understand how she got into her current situation.

She reports that she is currently using $1 / 2$ gram of heroin per day to function and feel comfortable. She is also drinking 5-6 beers per day. She is sexually active with Jack, and they never use protection. Lately, she has noticed that her breasts have become swollen and tender. She also has not had a period in the past 12 weeks. She is pretty sure she is pregnant, and is sure that it is Jack's baby. However, she is not sure since she has had to "turn tricks." She is also not sure she can stop using dope even though Jack wants her to keep the baby. She is scared the baby will come between them, and that Jack will look for someone else to "party with."

Suzanne states that she is really confused about her current situation, and the options available to her. She asks you to help her make some decisions. Her friend also told her to keep using dope even though she may be pregnant because "stopping would make it worse for the baby." She says, "I just don't know what to do. Will you please help me?!?" 


\section{APPENDIX B}

\section{CASE STUDY QUESTIONS}

1. What dangers do you see as you read this case? What are the dangers for Suzanne? What about for Jack? And, what are the dangers for the baby?

2. Based on your comprehensive assessment, what are the bio psychosocial factors that are influencing Suzanne's situation? How might the information in her bio psychosocial be useful in her diagnosis and treatment?

3. How might her drug use be impacting her family? How might this be impacting Suzanne and her ability to quit using?

4. As part of a competency based assessment, what are the strengths that you identified in the situation?

5. What are some diversity related issues that you would consider when working with Suzanne?

6. What treatment options would you offer Suzanne and why?

7. What community resources are available for health promotion and risk reduction, and what referrals would benefit Suzanne?

8. Is her girlfriend correct in her advice for Suzanne not to stop her heroin use if she is pregnant? Could the drugs impact her brain functioning and/or that of the child she is carrying? If so, why? If not, why?

9. What legal issues are of concern here? How will you deal with them (particularly if she decides to have the baby?)

10. Based on your professional background, how do you imagine working together as a team (nurse, social worker, and treatment provider) and respect your roles and scope of practice?

11. What role would interprofessional communication and collaboration play in improving the health outcomes for Suzanne and her family?

DiDominico, J. Case: Suzanne. In Seven Case Studies of People with Substance Abuse Problems. The Josiah Macy Foundation in New York City. (Modified for purpose of the class) 